\title{
Assessing Level and Effectiveness of Corrosion Education in the UAE
}

\author{
Hwee Ling Lim \\ Arts \& Sciences Program, The Petroleum Institute, P.O. Box 2533, Sas Al Nakheel Campus, Abu Dhabi, United Arab Emirates \\ Correspondence should be addressed to Hwee Ling Lim, hlim@pi.ac.ae \\ Received 14 November 2011; Accepted 7 January 2012 \\ Academic Editor: Yu Zuo \\ Copyright () 2012 Hwee Ling Lim. This is an open access article distributed under the Creative Commons Attribution License, \\ which permits unrestricted use, distribution, and reproduction in any medium, provided the original work is properly cited. \\ The consequences of corrosion can be minimized by an engineering workforce well trained in corrosion fundamentals and \\ management. Since the United Arab Emirates incurs the second highest cost of corrosion after Saudi Arabia, this paper examined \\ the quality of corrosion education in the UAE. Surveys with academia and industry respondents showed that dedicated corrosion \\ courses and engineering courses that integrated corrosion into the curricula were available in UAE universities, but graduates \\ had insufficient knowledge of corrosion engineering and superficial understanding of corrosion in real-life design contexts. The \\ effectiveness of corrosion education is determined by both competence in corrosion knowledge/skills and availability of resources \\ (faculty and research). Though most departments would not hire new corrosion-specialist faculty, department research efforts and \\ industry partnerships in corrosion research were present. The paper concluded with recommendations for improving knowledge \\ and skills of future engineers in corrosion and enhancing corrosion instruction to better meet industry needs.
}

\section{Introduction}

The annual cost of corrosion prevention and damage worldwide is estimated at US\$ 2.2 trillion (2010). In the United Arab Emirates (UAE), the annual cost of corrosion is US\$ 14.26 billion (2011 estimate) with most of the cost related to corrosion in its energy industry. Hence, it is vital that engineers in the oil and gas industry are technically competent in the control and management of corrosion. Much of this competence is gained through formal higher education. However, there is little research on the quality of corrosion education in the UAE.

This study aims to assess the quality of corrosion education in engineering programs of universities in the UAE. The research questions posed in this study are stated below.

RQ 1a: What is the level of corrosion instruction available in universities in the UAE?

$R Q 1 b$ : Why is such a level of corrosion instruction available in UAE universities?

$R Q$ 2a: How competent are the engineering undergraduates/graduates from UAE universities in corrosion knowledge and skills?
$R Q 2 b$ : What resources are available to UAE universities to support effective corrosion education?

Findings from this paper could help higher education institutions in the UAE identify possible shortcomings in their corrosion education programs. Accordingly, this paper has the potential to improve the knowledge base and skills of future engineers in the recognition and management of corrosion. Also, companies in the industrial sectors where corrosion has great impact would gain much needed information on the current quality of corrosion education in the engineering programs of UAE universities. Moreover, the recommendations provided could guide higher education institutions in enhancing their existing corrosion education programs to meet industry expectations better.

\section{Literature Review}

2.1. Corrosion: Definition and Causes. Corrosion is defined as the deterioration of metals or materials by chemical, biological or environmental agents $[1,2]$. It is a natural process involving the electrochemical oxidation of metals by an oxidant such as oxygen. "Rusting" is a typical corrosion process that is the formation of an oxide of iron due to 
oxidation of iron [3]. In the petrochemical refining industry, corrosion is caused by various natural constituents present in oil such as sulphur compounds, salt water, inorganic and organic acids, and nitrogen that form cyanides. In most oil and gas environments, $\mathrm{CO}_{2}$ and $\mathrm{H}_{2} \mathrm{~S}$ are mainly responsible for corrosion [4]. $\mathrm{CO}_{2}$ dissolves in water and forms carbonic acid that lowers the $\mathrm{pH}$ of the water, thus increasing its corrosiveness.

The oil/gas industry typically operates in very harsh environments such as deserts and deep seas. In such environments, corrosion is a very serious and challenging problem. Desert conditions can promote corrosion due to the presence of the following: alternating wet-dry weather cycles, high temperatures (around $50^{\circ} \mathrm{C}$ ) and high humidity for most of the year, erosion from strong winds and blowing sand; salinity of ground water, and Sabkha soil that causes discoloration of stainless steel (316) in three years, while in nondesert conditions there is typically no discoloration in 25 years.

Also, equipment in deep sea environments, such as offshore oil rigs and platforms, is constantly exposed to a wide range of environmental conditions; the equipment is particularly vulnerable to corrosion. In off-shore environment, corrosion severity can be related to location of equipment with respect to the ocean surface. For an oil platform, there are the atmospheric zone (degree of rainfall, sun and wind), splash zone (area wetted by wave action), and immersed zone (area below the water surface) [5]. The constant mixture of saltwater contact and oxygen interaction causes drilling tools and oil rig metallic supports to be more liable to corrosion [6]. In particular, $\mathrm{H}_{2} \mathrm{~S}$ in seawater is dangerously effective at corroding metals that can lead to the sinking of supports of the rigs into the seabed. Corrosion not only causes deterioration of materials but also poses economic and engineering problems for industries and countries.

\subsection{Impact of Corrosion: Financial Cost to the GCC States.} The annual cost of corrosion worldwide is estimated at US\$ 2.2 trillion (2010), which is about 3\% of the world's gross domestic product (GDP) of US\$ 73.33 trillion [7]. The UAE annual cost of corrosion is estimated at US\$ 14.26 billion (2011), which is about $5.2 \%$ of the country's GDP over three years (2009-2011). Among the GCC states, the UAE incurs the second highest annual cost of corrosion after Saudi Arabia (Figure 1).

The economies of the GCC states are highly dependent on the oil/gas industrial sectors. In particular, the UAE is estimated to account for $6.17 \%$ of Middle-East regional oil demand by 2014 , while providing $10.87 \%$ of supply. It also contributed $10.5 \%$ to 2010 regional gas production and is estimated to provide $10.19 \%$ of supply by 2014 [8]. Most of the costs related to corrosion are incurred in the following areas:

(i) degradation of the pipeline infrastructure for transportation and storage of natural gas, crude oil, and refined petroleum products,

(ii) corrosion of equipment involved in the production of corrosive crude oil from aging reservoirs,

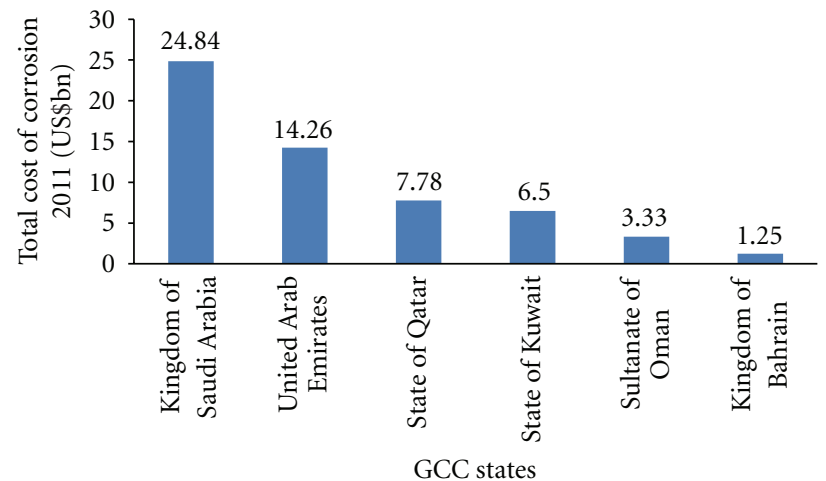

FIGURE 1: Annual cost of corrosion for GCC states (US\$ bn), 2011 estimate [7].

(iii) lost production due to downtime for corrosion inspection,

(iv) requirement for extensive chemical treatment to maintain the integrity of assets.

Corrosion-related failures constitute $25 \%$ of failures experienced in the oil/gas industry [4]. In five Saudi Aramco refineries, corrosion accounted for $13 \%$ of engineering costs and $36 \%$ of maintenance costs from 1999 to 2001 [9]. Moreover, the cost of shutting down units and plants can reach US\$20,000 to US\$ 50,000 per hour [3].

2.3. HSE Impact of Corrosion. The impact of corrosion is not only monetary but involves environmental, health, and safety risks as well. When poorly managed, corrosion affects equipment integrity and serviceability raising the risks of leaks and discharge of flammable fluids and gases that present serious health, safety, and environmental (HSE) hazards for which companies can be held liable [10]. For example, pipelines leaks can contaminate the nearby water sources and air. Also corrosion of plant equipment housing flammable materials can lead to fire hazards. In Rawdhatain, Kuwait (January 31, 2002), a pipe leak resulted in major explosions at an oil gathering center killing four people and three main facilities were destroyed; in Al-Ahmadi, Kuwait (June 25, 2000), a condensate line between an NGL plant and refinery failed in Kuwait's largest oil refinery. Five were killed and three crude units were damaged. The cause was an aging pipe that suffered erosion-corrosion and was not detected during inspection. Given the economic and HSE impact of corrosion on the oil/gas industry, professional knowledge in prevention and management of this problem is crucial. Hence, it is important to stress the role of corrosion education for engineers.

2.4. Importance of Corrosion Education for Engineers. As it is impossible to eliminate corrosion, corrosion management is the most feasible solution. The expertise of a corrosion engineer is required for managing corrosion, especially in hightemperature and high-pressure environments [6]. Given the importance of corrosion, it is difficult to understand why $54 \%$ of corrosion protection practitioners have not 
taken a course on corrosion during their formal education. Also, $45 \%$ of the currently active and experienced corrosion technologists are likely to retire in the next 10 years [10]. Hence, implementing a robust corrosion education system would help the oil/gas industry to reduce the long-term cost of corrosion; decrease the potential hazards from corrosion, and develop new corrosion-resistant materials, technologies, and processes for corrosion management.

2.5. Assessing Quality of Corrosion Education. Recently, in response to the threat corrosion poses to the national security infrastructure, the Department of Defense (DoD) commissioned a National Research Council (NRC) report to assess the state of corrosion engineering education in the United States. A Committee on Assessing Corrosion Education was formed to study the situation and reported its findings in 2009 [11]. The committee was commissioned to do the following:

(i) assess the level and effectiveness of existing engineering curricula in corrosion science and technology, including corrosion prevention and control,

(ii) recommend actions that could enhance the corrosion-based skill and knowledge base of graduating and practicing engineers [11, page 2].

The committee invited 83 US engineering schools to participate in an online survey and 31 institutions responded (37\% response rate). Out of the 31 returns, $61 \%$ were respondents from material science departments while the rest were from other departments. The report acknowledged that since the respondents were self-selected and largely institutions already involved in corrosion education, the results probably presented an overly positive picture of the real situation and should be interpreted with some caution.

The findings showed that corrosion is taught mainly as a part of other courses in responding universities rather than as a specific course. When a dedicated corrosion course is available, it is likely to be an elective offered to undergraduates and graduates. However, when corrosion is taught (integrated) in other courses, the courses are mostly required and offered at undergraduate level with only a few lectures spent on the discussion of corrosion. Moreover, dedicated corrosion courses are likely to have lower enrolment numbers (smaller class size) compared to courses that integrate corrosion into their syllabi. Since the committee presented the most recent large scale survey on the current state of corrosion education in higher education, this study replicates in part its questionnaire design for a more meaningful comparison of findings.

2.6. Summary of the Review. Although corrosion is an inevitable natural process, the economic, environmental, and societal consequences of corrosion failure in oil/gas operations can be minimized and managed by an engineering workforce that is properly educated in corrosion fundamentals and adequately trained in corrosion management. Moreover, a knowledgeable workforce can contribute to developments in corrosion prevention technologies that are vital to improving efficiency in energy production. Findings from the National Research Council report [11] provided an up-to-date description of corrosion education available in the USA but there is currently no equivalent study available in the UAE. With the cost of corrosion increasing steadily, there is an urgent need for research on the quality of corrosion engineering education in the UAE. The next section describes the methodological design of this study.

\section{The Case Research Methodology}

3.1. The Single-Embedded Case: Units of Analysis and Sampling Strategy. This research used a single-embedded case design whereby within a single case, attention also is given to subunits [12]. The single-embedded case design presents the advantage of in-depth analyses of subunits that provide insight into the main case. Since this qualitative study aims to examine the quality of corrosion education in engineering programs of UAE universities, the main case is the engineering education program while four universities are subunits nested within the primary case (Figure 2).

A purposive sampling approach was adopted and the following criteria were used in subunit selection:

(i) location of the higher education institution in the UAE,

(ii) availability of engineering degree programs in the institution,

(iii) availability of engineering programs in which corrosion is relevant (this excludes institutions that offer engineering programs such as software/informationtechnology only),

(iv) the higher education institution must have graduated at least one cohort of students,

(v) reliable accessibility and cooperation from universities/participants for research.

Four institutions were identified that met all the criteria. Three institutions are located in the emirate of Abu Dhabi and one institution is in Sharjah. Due to the ethical consideration of confidentiality, the universities were pseudonymised (as University A, B, C, D), and identifying information was removed in the reporting of this study.

3.2. Data Sources. The primary data sources were academics from the four educational institutions and respondents from the oil/gas industry. The total sample size was 66 respondents. Respondents from academia $(n=58)$ included faculty, teaching assistants, and laboratory instructors. Also, engineers $(n=8)$ from a major oil/gas company were interviewed to understand employers' perspective on the competence of engineering graduates in corrosion. The secondary data sources were the organizations, namely, university prospectuses and websites that provided archival data on the engineering programs and curricula available in the institutions. 


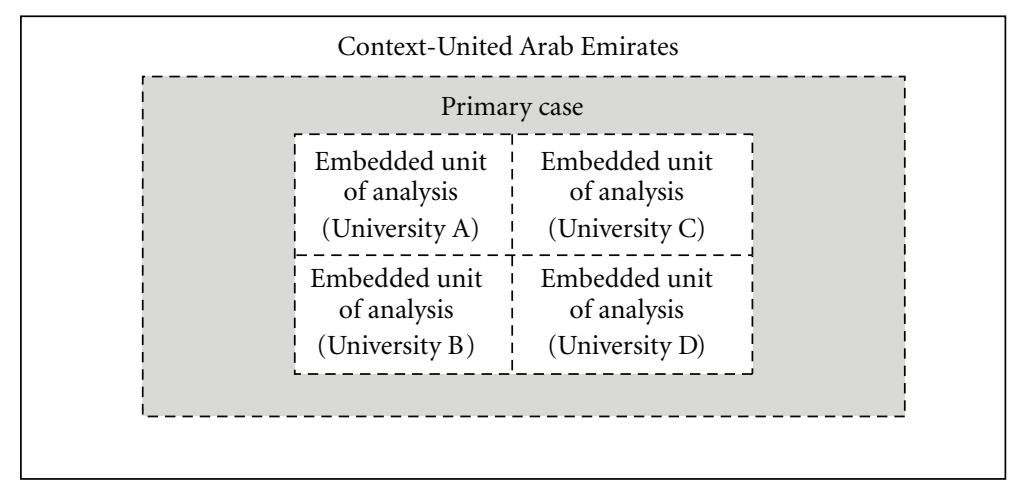

Figure 2: Single-embedded case design in this study (adapted from [13, page 40]).

3.3. Instruments. A survey questionnaire (Questionnaire A) and an interview questionnaire (Questionnaire B-1 and B-2) were used. Questionnaires A and B-1 were self-administered surveys (i.e., participants completed the questionnaires on their own) that were delivered to respondents via email or face-to-face. However, Questionnaire B-2 was administered via face-to-face interviews (individual or focus group) depending on the participants' preferences. The focus group size ranged from 2 to 4 respondents per group. Interviews were used to follow up and elicit elaborations on responses provided in Questionnaire B-1 that were completed earlier by participants. Also, all interviews were audio recorded to ensure that the views of the respondents were accurately represented. Table 1 summarizes the instruments and respondent distribution.

3.4. Constructs and Measures. The questionnaires had five main parts (Parts A-E) and 37 questions (closed and openended) that captured information on respondent demographics, level of existing engineering curricula in corrosion, effectiveness of engineering curricula in corrosion, and recommendations for enhancing corrosion knowledge and skills. Table 2 summarizes the constructs and questions that constitute the operationalized measures of the constructs.

The construct level of existing engineering curricula in corrosion is defined as the extent of corrosion instruction available. The construct is operationalized by a question (Q.10) that measures availability of corrosion instruction on a scale from having a dedicated corrosion course, teaching corrosion as a part of other courses (integrated), to not teaching corrosion at all.

The construct effectiveness of existing engineering curricula in corrosion is defined as the degree to which the course produces the desired instructional outcomes measured as

(i) level of competence in corrosion knowledge and skills of engineering undergraduates/graduates (Q.34-35),

(ii) availability of resources to achieve the desired outcomes (Q.29, 32-33).

3.5. Data Analysis and Validity Issues. Quantitative and qualitative data were gathered, respectively, from closed and open-ended questions in the instruments. While the quantitative data was presented as descriptive statistics, qualitative responses in the survey and interview datasets were subjected to interpretive content analysis to derive main themes.

The reliability of a study entails the demonstration that operations can be repeated with the same results. This study acknowledges subjectivity with the use of a single case and that knowledge gained is based on interpretations in a specific time/context and not be claimed to be generalizable to whole populations. However, the standard of authenticity [14] is adopted and the qualitative study's methodological design emphasized the use of multiple data sources and methods (Sections 3.2 and 3.3) for capturing "rich" descriptions that add to credibility of the findings. Diverse perspectives from academia and industry participants were gathered for triangulation rather than the confirmation of a single interpretation of the quality of corrosion education in the universities.

While external validity, as generalizability of the findings, is moot in this single case study, internal validity is relevant in terms of content and construct validity of the instruments. Both issues were addressed by piloting and refining the instruments during which questions were added, discarded, rephrased, and reordered that improved clarity and layout of the instruments.

3.6. Ethical Considerations. Research ethics is the application of fundamental and moral principles of respect for autonomy, beneficence, and justice in doing research [15]. In this study, ethical issues of informed consent, voluntary participation, and confidentiality were relevant. Informed consent refers to the necessity of providing respondents with an understanding participation of the vouluntary, the purpose of the research, anticipated consequences of participation and factors which could reasonably influence their decision. Voluntary participation refers to the right to privacy and the right not to answer specific questions. Since forced participation may cause respondents to withhold vital information, obtaining voluntary participation is critical. Confidentiality means that the real identities of participants would not be revealed in the dissemination of findings. Being professionals in their respective fields, any direct linkage of 
TABLE 1: Instruments and respondent distribution.

\begin{tabular}{|c|c|c|c|c|c|c|}
\hline \multirow{2}{*}{ Subunit } & \multicolumn{2}{|c|}{ Survey } & \multicolumn{2}{|c|}{ Interview } & \multirow[b]{2}{*}{$\begin{array}{l}\text { Focus Group } \\
\text { (Industry) }\end{array}$} & \multirow[b]{2}{*}{ Total } \\
\hline & Face-to face & E-mail & $\begin{array}{c}\text { Individual } \\
\text { (Academia) }\end{array}$ & $\begin{array}{c}\text { Focus Group } \\
\text { (Academia) }\end{array}$ & & \\
\hline University A & $n=10$ & - & - & - & - & 10 \\
\hline University B & - & $n=9$ & - & $\begin{array}{c}1 \mathrm{FG}^{*} \\
(n=3)\end{array}$ & - & 12 \\
\hline University C & $n=11$ & - & $n=2$ & $\begin{array}{c}1 \mathrm{FG} \\
(n=3)\end{array}$ & - & 16 \\
\hline University D & $n=9$ & - & - & $\begin{array}{c}3 \mathrm{FG} \times 3 \operatorname{Resp} \\
1 \mathrm{FG} \times 2 \text { Resp } \\
(n=11)\end{array}$ & - & 20 \\
\hline - & - & - & - & - & $\begin{array}{c}2 \mathrm{FG} \times 4 \mathrm{Resp}^{*} \\
(n=8)\end{array}$ & 8 \\
\hline Total & & & 2 & 17 & 8 & 66 \\
\hline
\end{tabular}

${ }^{*}$ FG, focus group; Resp, respondent.

TABLE 2: Measures for constructs.

\begin{tabular}{ll}
\hline Construct & Measures as survey questions* \\
\hline & Q10. Does your department offer a course or courses specifically in corrosion? \\
Level of existing engineering curricula in corrosion & (a) Yes, my department offers course(s) specifically in corrosion \\
& (b) No, my department teaches corrosion as part of other courses \\
& (c) No, corrosion is NOT taught at all in my department
\end{tabular}

Effectiveness of existing engineering curricula in corrosion

Q34. Do you think engineering undergraduates/graduates (from your university) have sufficient fundamental knowledge of corrosion engineering? Please explain.*

Level of competence in corrosion knowledge and skills

Q35. Do you think engineering undergraduates/graduates (from your university) have sufficient understanding of the importance of corrosion in engineering design? Please explain.*

Q29. Would your department consider hiring a faculty member whose technical focus is corrosion?

(a) Yes

(b) No

Q32. Is your department doing any corrosion-specific research? If so, who is funding it?

Availability of resources (manpower, knowledge)
(a) No
(b) Yes, funding organization(s):

Q33. Do you have any actual or potential partnerships with industry to study corrosion or develop continuing education for practicing engineers?

(a) No

(b) Yes

If so, please describe your partnerships with industry to study corrosion

*Industry respondents answered a variation of Q34/35 that excluded reference to "from your university."

participants' personal views to their actual identities may jeopardize their positions in the institutions. These issues were handled by a cover letter and informed consent form that were read, understood, and signed by participants prior to taking part. Confidentiality was ensured by deleting compromising details and replacing actual names and identities of employer institutions with pseudonyms in data processing and publication.

\section{Results and Discussion}

4.1. Overview of Institutions and Respondents. Most of the academia respondents were male, aged $31-50$ years (67\%), with more than 10 years work experience. Most had higher education degrees (Ph.D., M.S. degrees), held positions from professors to lab instructors in various departments (mechanical, civil, and chemical engineering). The industry 
respondents were all employed by a major oil/gas company, most were also male but younger ( $75 \%$ below 40 years), with more than 10 years work experience. Most had bachelor's degrees and in positions ranging from heads of engineering divisions to senior/specialist engineers.

4.2. RQ 1a: What Is the Level of Corrosion Instruction Available in Universities in the UAE? The level of corrosion instruction available is measured on a scale from having a dedicated corrosion course, teaching corrosion as a part of other courses (integrated), and not teaching corrosion at all. Although the departments in University A that were surveyed offered engineering programs in which corrosion would be relevant (civil engineering, master of engineering management), it was found that corrosion was not taught at all by the departments.

The remaining three universities offered dedicated corrosion courses and taught corrosion as a part of other courses as well (Table 3 ). The dedicated corrosion courses were mainly electives, offered once a year at undergraduate level, included laboratory work and class size ranged from 20 to 50 students (Table 4). The courses that integrated corrosion into their curricula were offered at undergraduate and graduate levels (mixed) and only a few lectures were devoted to corrosion (Table 5).

Compared to the NRC report [11], the structure of dedicated and integrated corrosion courses were similar except in two minor areas. In the UAE universities, the dedicated corrosion course class size tended to be larger (2050 students per class) and the integrated courses were mainly offered to both levels rather than just at undergraduate level.

4.3. RQ 1b: Why Is Such a Level of Corrosion Instruction Available in UAE Universities? Open-ended questions were used to probe for reasons for the level of corrosion instruction available in the institutions. Academia respondents explained that dedicated corrosion courses were offered due to concerns over corrosion's economic and HSE impact on industries. In contrast, the reasons cited in the NRC report were broader, including employer demand, student interest and relevance to engineering careers. However, when corrosion is not taught at all in departments, the main reasons given below were consistent with the NRC report:

(i) other engineering topics have more priority,

(ii) faculty not available for teaching corrosion.

4.4. RQ 2a: How Competent Are the Engineering Undergraduates/Graduates from UAE Universities in Corrosion Knowledge and Skills? Academia and industry respondents were interviewed regarding their perceptions of engineering undergraduates/graduates as having

(a) sufficient fundamental knowledge of corrosion engineering (Q.34),

(b) sufficient understanding of the importance of corrosion in engineering design (Q.35).
TABLE 3: Level of existing engineering corrosion curricula available.

\begin{tabular}{lcccc}
\hline Q. 10 & $\begin{array}{c}\text { University } \\
\text { A }\end{array}$ & $\begin{array}{c}\text { University } \\
\text { B }\end{array}$ & $\begin{array}{c}\text { University } \\
\text { C }\end{array}$ & $\begin{array}{c}\text { University } \\
\text { D }\end{array}$ \\
\hline $\begin{array}{l}\text { Dedicated } \\
\text { course(s) in } \\
\text { corrosion }\end{array}$ & - & Yes & Yes & Yes \\
$\begin{array}{l}\text { Corrosion } \\
\text { covered in other } \\
\text { courses }\end{array}$ & - & Yes & Yes & Yes \\
$\begin{array}{l}\text { Corrosion not } \\
\text { taught at all }\end{array}$ & Yes & - & - & - \\
\hline
\end{tabular}

The consensus was that engineering undergraduates/ graduates showed insufficient fundamental knowledge of corrosion engineering due to the limited scope of corrosion in the curricula. Moreover, industry respondents highlighted the need to link theory and practice in the courses, while academia respondents cited the elective status of corrosion courses as contributing to the situation.

In contrast, respondents from University B maintained that their students had sufficient fundamental knowledge, which they attributed to the quality of their course materials: "Our students have good background knowledge because the material covered is up to date" (01.G2.R1).

Since competence involves having fundamental knowledge as well as skills in application, respondents were asked whether undergraduates/graduates understood the importance of corrosion as evidenced in their practical engineering designs. Most academia respondents held the positive view that there was sufficient understanding of the importance of corrosion in design as shown by students' awareness of the impact of corrosion and good grades and laboratory skills. However, the industry respondents were more critical in their view that graduate engineers showed superficial understanding of corrosion because of the lack of skills in application of theoretical knowledge in engineering design.

As the course status (required or elective) impacts the extent of knowledge/skills developed in the subject, views were gathered on whether corrosion engineering should be a required course in engineering degree programs. Interestingly, both academia and industry respondents were ambivalent on the issue. The position that corrosion engineering should be a required course was taken because such knowledge would be needed in the future for corrosion management in many industries. However, the opposing view that it should be an elective course was held due to the limited relevance of corrosion in some engineering fields and concern over excessive course workload.

4.5. RQ 2b: What Resources Are Available to UAE Universities to Support Effective Corrosion Education? The effectiveness of existing engineering curricula in corrosion is determined by both competence in corrosion knowledge/skills and availability of resources (as manpower, new knowledge through research) to achieve the desired instructional outcomes. 
TABle 4: Details on dedicated corrosion courses.

\begin{tabular}{|c|c|c|c|c|}
\hline \multicolumn{5}{|c|}{ Dedicated corrosion courses } \\
\hline & University A & University B & University C & University D \\
\hline Class level & - & Undergraduate & Undergraduate & Mixed* \\
\hline Class size* & - & Fewer than $2020-50$ & $20-50$ & Fewer than $2020-50$ \\
\hline Required or elective & - & Required & Elective & Elective \\
\hline Availability** & - & Once a year & Once a year & Every semester Once a year \\
\hline Lab-based course & - & Available & Available & Available \\
\hline \multirow{4}{*}{ Course name ${ }^{\#}$} & - & (i) Corrosion & (i) Corrosion & (i) Material science \\
\hline & & (ii) Introduction to corrosion & & (ii) Corrosion engineering \\
\hline & & (iii) Materials and corrosion & & (iii) Advanced physical chemistry \\
\hline & & & & (iv) Corrosion chemistry \\
\hline
\end{tabular}

${ }^{*}$ Class size: number of students enrolled per class. ${ }^{* *}$ Availability: some of the courses were available once a year, others were available every semester. ${ }^{*}$ Course name: courses listed based on participants' own interpretations of how much corrosion content was taught in the course.

TABLE 5: Details on courses that integrate corrosion in curricula.

\begin{tabular}{|c|c|c|c|c|}
\hline \multicolumn{5}{|c|}{ Courses that integrate corrosion into curricula } \\
\hline & University A & University B & University C & University D \\
\hline Class level & - & Mixed* & Mixed & Mixed \\
\hline \multirow[t]{2}{*}{$\begin{array}{l}\text { Time devoted } \\
\text { to corrosion }\end{array}$} & - & A few lectures & A few lectures & A few lectures \\
\hline & & $\begin{array}{l}\text { (i) Civil engineering } \\
\text { construction }\end{array}$ & (i) Material sciences & (i) Production engineering \\
\hline \multirow[t]{3}{*}{ Course name } & - & (ii) Construction materials & (ii) Construction materials & $\begin{array}{l}\text { (ii) Production and surface } \\
\text { facilities }\end{array}$ \\
\hline & & (iii) Materials and corrosion & (iii) Physical chemistry & (iii) Mechanics of materials \\
\hline & & (iv) Chemistry for civil engineers & & $\begin{array}{l}\text { (iv) Failure analysis and } \\
\text { prevention }\end{array}$ \\
\hline
\end{tabular}

* Mixed: undergraduate and graduate levels.

Academia respondents were surveyed on the availability of qualified faculty and research in their departments to support corrosion education. Regarding manpower, departments in three out of the four universities would not hire faculty whose technical focus is corrosion because other topics have more priority. Interestingly, University D was the only institution where departments would hire corrosionspecialist faculty to fill newly created positions (Table 6).

The main reason cited for not recruiting a new faculty was consistent with the NRC report (Table 7). However, most of the US university respondents would hire a corrosion specialist faculty to fill a vacancy rather than a new position. This suggests that the need for qualified faculty in corrosion is being recently recognized in UAE institutions of higher education.

Regarding research, departments in three out of the four universities conducted corrosion research in varying extent, while only Universities C and D reported availability of both department research and industry partnerships in corrosion research (Table 8). In the NRC report, research funding was obtained mainly from federal agencies but the Abu Dhabi National Oil Company (ADNOC) and its operating
TABLE 6: Resources: faculty recruitment.

\begin{tabular}{lcccc}
\hline \multirow{2}{*}{ Part C } & \multicolumn{4}{c}{ Corrosion-specialist faculty recruitment } \\
& $\begin{array}{c}\text { University } \\
\text { A }\end{array}$ & $\begin{array}{c}\text { University } \\
\text { B }\end{array}$ & $\begin{array}{c}\text { University } \\
\text { C }\end{array}$ & $\begin{array}{c}\text { University } \\
\text { D }\end{array}$ \\
\hline $\begin{array}{l}\text { Hire corrosion- } \\
\text { specialist } \\
\text { faculty }\end{array}$ & $0 \%$ & $8 \%$ & $6 \%$ & $55 \%$ \\
$\begin{array}{l}\text { Do not hire } \\
\text { corrosion- } \\
\text { specialist } \\
\text { faculty }\end{array}$ & $100 \%$ & $92 \%$ & $94 \%$ & $45 \%$ \\
\hline
\end{tabular}

companies were cited by University D as the main sponsors and industry partners in corrosion research.

4.6. Summary of Findings. Regarding the level of corrosion instruction, this study found that dedicated corrosion courses and engineering courses that integrated corrosion into the curricula were available in UAE universities. While 
TABLE 7: Reasons for corrosion faculty recruitment.

Reasons for hiring faculty*

\begin{tabular}{lc}
\hline Fill a newly created position & $77 \%(10)$ \\
Fill a vacancy due to a retiring or newly retired & $15 \%(2)$ \\
faculty member & $8 \%(1)$ \\
Others & \\
\hline Reasons for NOT hiring faculty* & $60 \%(27)$ \\
\hline Other topics have more priority & $7 \%(3)$ \\
Limited department budget & $33 \%(15)$ \\
\hline
\end{tabular}

${ }^{*}$ Based on 58 academia respondents.

TABLE 8: Resources: research.

\begin{tabular}{lcccc}
\hline Part C & $\begin{array}{c}\text { University } \\
\mathrm{A}\end{array}$ & $\begin{array}{c}\text { University } \\
\mathrm{B}\end{array}$ & $\begin{array}{c}\text { University } \\
\mathrm{C}\end{array}$ & $\begin{array}{c}\text { University } \\
\mathrm{D}\end{array}$ \\
\hline $\begin{array}{l}\text { Corrosion research } \\
\text { carried out by } \\
\text { department }\end{array}$ & $10 \%$ & $0 \%$ & $25 \%$ & $55 \%$ \\
$\begin{array}{l}\text { Industry research } \\
\text { partnership }\end{array}$ & $0 \%$ & $0 \%$ & $13 \%$ & $25 \%$ \\
available & & & & \\
\hline
\end{tabular}

the dedicated courses were offered due to concerns over corrosion's economic and HSE impact, in cases where corrosion was not taught at all, it was because other engineering topics had greater priority and a lack of qualified faculty.

Concerning the competence of engineering undergraduates/graduates in corrosion knowledge and skills, the consensus view of academia and industry respondents was that there was insufficient fundamental knowledge of corrosion engineering due to the limited scope of corrosion in the curriculum. Moreover, the elective status and lack of effective links between theory and practice in corrosion courses contributed to the situation. Unusually, both academia and industry respondents were ambivalent on the issue of making corrosion a required course in engineering degree programs.

Besides having fundamental knowledge of corrosion, another dimension of competence is the ability to apply the theoretical knowledge in practice. Interestingly, while academia respondents held the positive view that the students displayed sufficient understanding of the importance of corrosion in engineering design, the industry respondents were more critical in their perception that graduate engineers had only superficial understanding of corrosion in real-life design contexts.

The effectiveness of engineering curricula in corrosion is determined by not only competence in corrosion knowledge/skills but also the availability of resources (as qualified faculty, development of new knowledge through research) to support corrosion education. Unfortunately, most departments would not hire corrosion-specialist faculty members because other topics have more priority. However, the aspect of research is more encouraging with two universities reporting availability of both department research and industry partnerships in corrosion research.

\section{Conclusion and Recommendations}

5.1. Quality of Corrosion Education in the United Arab Emirates. The overarching aim of this study is to assess the quality of corrosion education in engineering programs of universities in the United Arab Emirates. The singleembedded case design adopted designated the engineering education program as the primary case and four universities formed the subunits for comparison. Between-unit comparisons of corrosion curricula characteristics were carried out in Section 4. The focus now returns to the primary case and the findings are compared to two theoretical ideal cases.

Ideal Case No.1. if corrosion is taught in the university (as dedicated and/or integrated courses), then the students/graduates would have sufficient fundamental knowledge of corrosion and skills in the application of such knowledge in practical engineering design. Also, the university would have enough resources, as qualified faculty and knowledge from research, to support corrosion education.

Ideal Case No. 2. if corrosion is not taught in the university, then the students/graduates would not have sufficient fundamental knowledge of corrosion nor skills in the application of such knowledge in practical engineering design. Also, the university would not have the resources to support corrosion education.

Table 9 shows that each subunit revealed a dimension of the phenomenon under study. It is clear that two universities were situated at opposite ends of the spectrum. University D most closely reflected Ideal Case \#1 whereas University A most closely represented Ideal Case \#2. The remaining universities embodied variations along the scale. Within the subunits, there appeared to be discrepancies in the results that could be explained. The results for University A showed that although corrosion is not taught at all, corrosion research is carried out and this could be due to individual faculty's own effort to conduct corrosion research even though corrosion is not taught as a course. It is not unusual to observe differences between what the faculties teach and their research areas. The findings for University B showed that it offers dedicated corrosion courses but has no manpower for this activity. This project defined manpower as the availability of corrosion specialist faculty to teach corrosion courses (Table 2, Q.29). Hence, the survey asked faculty respondents if their departments would consider hiring a faculty whose technical focus is corrosion (yes/no option). Hence the data in Table 9 indicated that even as University B offers dedicated corrosion courses, the departments do not intend to recruit corrosion specialist faculties to teach the courses.

An interesting inconsistency emerged in the divergent perceptions held by academia and industry respondents regarding competence in corrosion engineering. According to the academics, the students had sufficient application skills but industry respondents held the unanimous view that graduate engineers lacked both fundamental corrosion 
TABLE 9: Overview of findings.

\begin{tabular}{|c|c|c|c|c|c|c|}
\hline & \multicolumn{2}{|l|}{$\begin{array}{l}\text { Level of corrosion } \\
\text { instruction }\end{array}$} & \multicolumn{4}{|c|}{ Effectiveness of engineering curricula in corrosion } \\
\hline & Availability & $\begin{array}{c}\text { Fundamental } \\
\text { knowledge }\end{array}$ & $\begin{array}{c}\begin{array}{c}\text { Skills } \\
\text { application }\end{array} \\
\end{array}$ & Manpower & $\begin{array}{c}\text { Department } \\
\text { research }\end{array}$ & $\begin{array}{c}\text { Research } \\
\text { partnerships }\end{array}$ \\
\hline $\begin{array}{l}\text { Ideal case } \\
\text { no. } 1\end{array}$ & Yes & Yes & Yes & Yes & Yes & Yes \\
\hline $\begin{array}{l}\text { Ideal case } \\
\text { no. } 2\end{array}$ & No & No & No & No & No & No \\
\hline University A & No & - & - & No & Yes & No \\
\hline University B & Yes & Yes & Yes & No & No & No \\
\hline University C & Yes & No & Yes & No & Yes & Yes \\
\hline University D & Yes & No & Yes & Yes & Yes & Yes \\
\hline Industry & NA & $\mathrm{No}^{*}$ & $\mathrm{No}^{*}$ & NA & $\mathrm{NA}$ & NA \\
\hline
\end{tabular}

* Industry respondents.

knowledge and skills in the application of corrosion knowledge in real workplace engineering design situations. This inconsistency could be explained by the different standards used by academia and industry respondents in assessing competence. While the academia respondents measured competence as the presence of good grades and laboratory skills, industry respondents expected graduate engineers to be competent at integrating the theoretical and applied aspects of corrosion in actual practice.

In terms of the overall quality of corrosion education, this study concluded that although corrosion was taught by most engineering programs of UAE universities, there were inadequate resources to support corrosion education in the forms of corrosion-specialist faculty members as well as new knowledge gained from department research efforts and industry partnerships in corrosion research.

\subsection{Recommendations for Enhancing Corrosion Knowledge} and Skills. In both the surveys and interviews, respondents were asked to suggest strategies for enhancing corrosion knowledge and skills of engineering undergraduates. Three main themes emerged from the suggestions and verbatim quotes were provided to more accurately reflect the voices of the respondents and support the suggestions. This study offers the following recommendations to engineering faculty and higher education institutions for improving the knowledge base and skills of future engineers in corrosion management as well as enhancing existing corrosion instruction to better meet industry expectations.

(i) Set corrosion course as required course in the curriculum framework of engineering fields where corrosion is particularly relevant so that a common level of knowledge and skills could be established.

"...engineers in mechanical, chemical and petroleum [engineering should] have to take it as a full subject" (01.G1.F3).

(ii) Integrate corrosion theory with practical experience in engineering courses and senior design projects so that undergraduates could be actively involved in the application of corrosion theory in actual design processes.

"Undergraduates in engineering curriculum should go on site visits with corrosion specialists ... to have hands-on training on any refinery or petrochemical plant." (01.G1.F1)

“... include corrosion in senior projects regarding means of protection" (03.G1.R5)

"Get undergraduates to get involved in the oil industries-like studies and investigation studies regarding failures." (01.G1.A4)

(iii) Promote awareness of corrosion impact through campus-wide workshops and activities such as Corrosion Awareness Day so as to raise students' appreciation of the need for corrosion mitigation and management.

"...provide workshops in corrosion" (03.G3.R8)

"... invite some people from the industry... awareness day" (03.G3.R7)

"Bring experts to share problems (related to corrosion) with students" (03.G3.R6).

5.3. Limitations of Study and Future Research. In order to assess the quality of corrosion education in engineering programs of universities in the UAE, a qualitative case study approach was used and certain characteristics inherent in the research design resulted in two main limitations. The first limitation concerns the single-embedded case design whereby only four universities were selected as subunits within the main case. While each subunit reflected a dimension of the phenomenon that illuminated the questions under study, the results are not claimed to be generalizable to 
whole populations. However, the implications for enhancing quality of corrosion education derived from the findings may be extrapolated to contexts beyond the UAE.

The second limitation concerns the quality of selfreported data from interviews. Academia respondents from University B who were interviewed held the position that their students were competent (having fundamental knowledge, application skills) in corrosion engineering yet no resources (qualified faculty, research) were reported to be available in the departments to support corrosion education. It is possible that the interview questions, which required respondents to self-assess the effectiveness of their engineering curricula in corrosion, had prompted socially desirable responses that made the respondents look "good" based on fears of jeopardizing their position at the university. These main limitations are acknowledged but do not detract from the value of the findings. Instead, they indicate several avenues for future research.

Since this study showed the feasibility of the research area and validity of instruments and protocols, researchers could expand on this study with a larger sample of subunits. Besides the four universities involved, there were other universities in the UAE that matched most of the criteria (Section 3.1) except the criterion of reliable accessibility and cooperation from universities/participants. The dissemination of findings from this paper could convince other universities to participate in future studies.

Additionally, comparative studies could be conducted that examine differences in the quality of corrosion education in other Middle-East countries. Major oil/gas producing countries such as Qatar, Saudi Arabia, and Kuwait have established universities that offer extensive engineering programs. For instance, Texas A\&M University in Qatar; Qatar University, King Abdullah University of Science and Technology, King Fahd University of Petroleum and Minerals, and Kuwait University. Hence, such studies could capture a more complete picture of the quality of corrosion education in a region where corrosion prevention and management are extremely crucial to its petroleum-based economies.

\section{References}

[1] Z. Ahmad, Principles of Corrosion Engineering and Corrosion Control, Butterworth-Heinemann, Oxford, UK, 2006.

[2] P. Roberge, Corrosion Engineering: Principles and Practice, McGraw-Hill Professional, New York, NY, USA, 2008.

[3] S. Bradford, Corrosion Control, ASM International, Edmonton, Ohio, USA, 2nd edition, 2002.

[4] C. J. Cron and G. A. Marsh, "Overview of economic and engineering aspects of corrosion in oil and gas production," Journal of Petroleum Technology, vol. 35, no. 7, pp. 1033-1041, 1983.

[5] M. B. Kermani and D. Harrop, "The impact of corrosion on the oil and gas industry," SPE Production and Facilities, vol. 11, no. 3, pp. 186-190, 1996.

[6] D. Brondel, R. Edwards, A. Hayman, D. Hill, S. Mehta, and T. Semerad, "Corrosion in the oil industry," Oilfield Review, vol. 6, no. 2, pp. 4-18, 1994.
[7] A. Al Hashem, "Corrosion in the Gulf Cooperation Council (GCC) states: statistics and figures," in Proceedings of the Corrosion UAE, Abu Dhabi, UAE, 2011.

[8] Business Monitor International, United Arab Emirates Oil and Gas Report Q4 2010, Business Monitor International Ltd, London, UK, 2010.

[9] R. Tems and A. Al-Zahrani, "Cost of corrosion in gas sweetening and fractionation plants," in Proceedings of the 61st Annual Conference and Exposition on Corrosion NACE Expo, pp. 1-12, San Diego, Calif, USA, 2006.

[10] D. Rose, "Current practice: the teaching of corrosion in colleges and universities," in Materials Forum 2007: Corrosion Education for the 21st Century, pp. 8-12, Washington, DC, USA, 2007.

[11] National Research Council, Assessment of Corrosion Education, The National Academy of Sciences, Washington, DC, USA, 2009.

[12] R. Yin, Case Study Research: Design and Methods, Sage, Beverly Hills, Calif, USA, 2nd edition, 1994.

[13] R. Yin, Case Study Research: Design and Methods, vol. 5, Sage, Thousand Oaks, Calif, USA, 3rd edition, 2003.

[14] M. Patton, Qualitative Research and Evaluation Methods, Sage, Thousand Oaks, Calif, USA, 3rd edition, 2002.

[15] I. Holloway and S. Wheeler, "Ethical issues in qualitative nursing research,” Nursing Ethics, vol. 2, no. 3, pp. 223-232, 1995. 

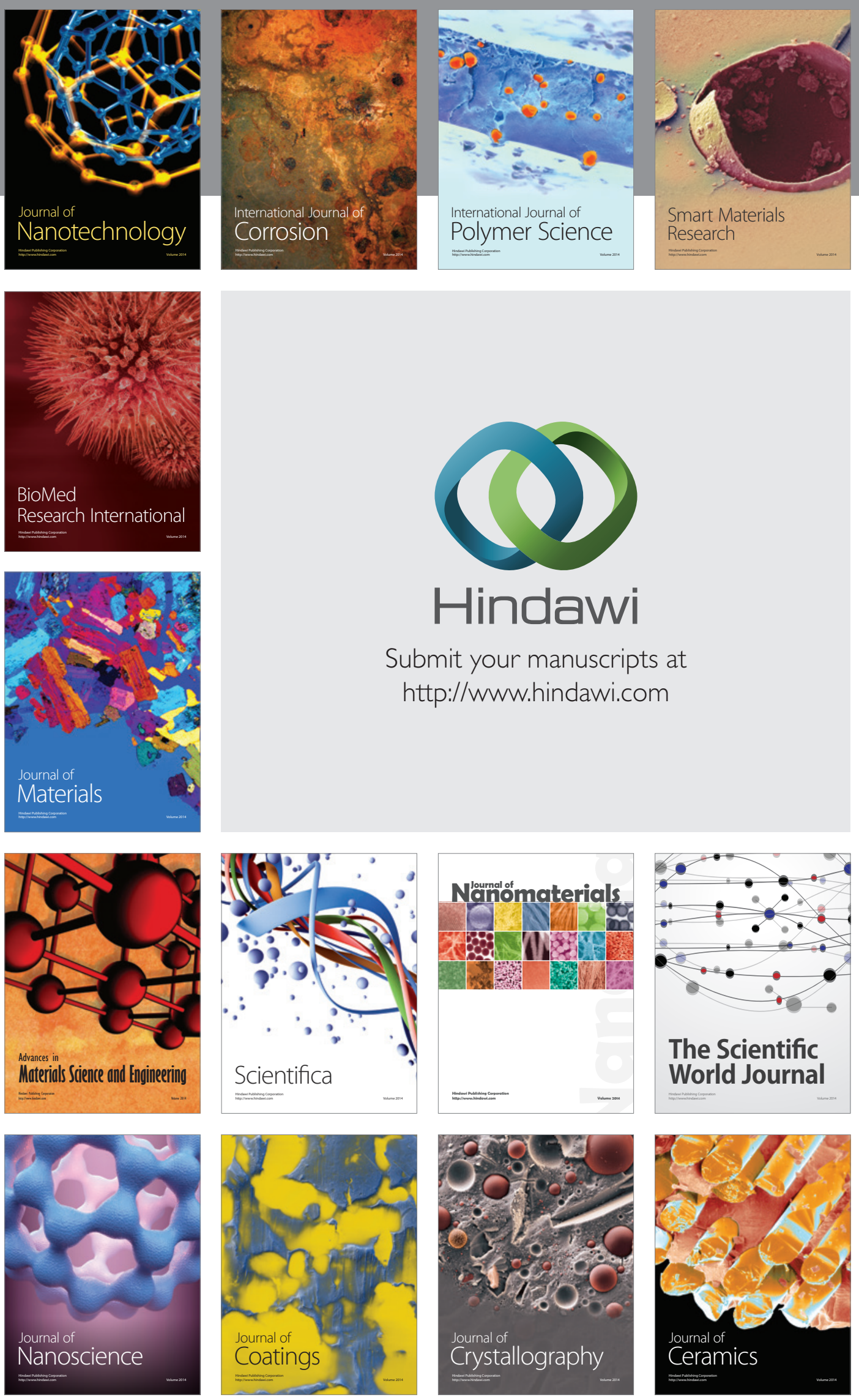

The Scientific World Journal

Submit your manuscripts at

http://www.hindawi.com

\section{World Journal}

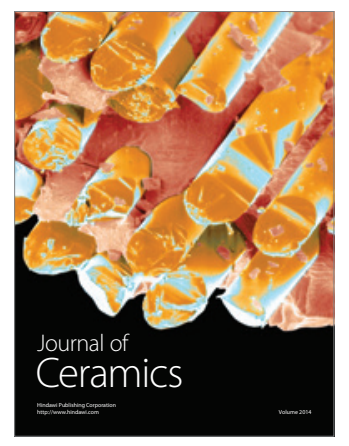

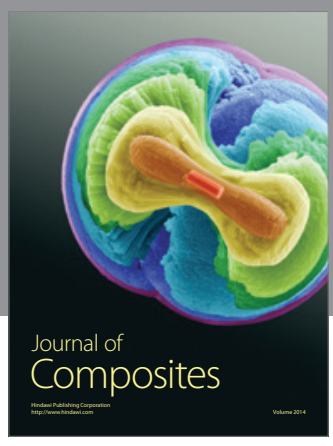
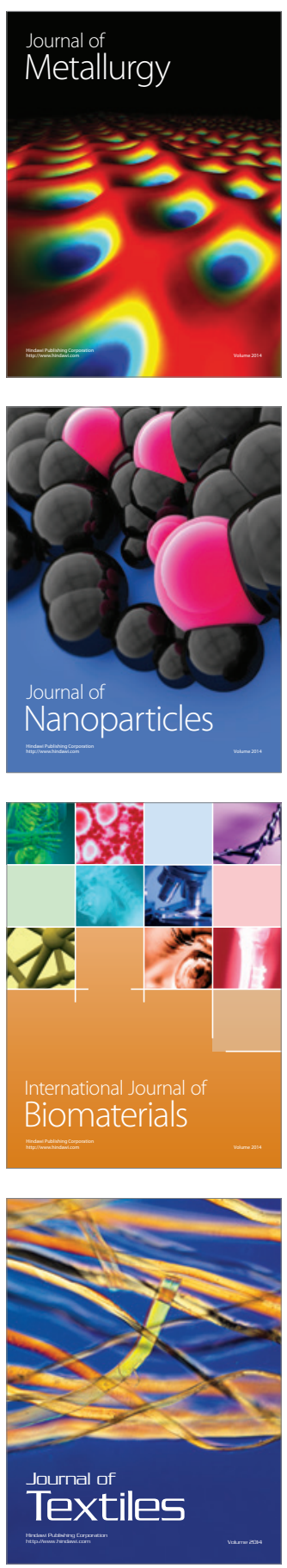